HStud 27 (2013)2, 277-290 DOI: 10.1556/HStud.27.2013.2.6

\title{
THE TRANSITIONAL EMPIRE
}

\section{CHARLES INGRAO and JOVAN PEŠALJ}

\author{
Purdue University \\ West Lafayette, IN, USA \\ E-mails: ingrao@purdue.edu, pesalj@gmail.com
}

\begin{abstract}
The Habsburg monarchy was conceived in 1527 as a borderland when the Ottoman march into the Pannonian plain united the Austrian, Bohemian and Hungarian lands. The latter's vulnerability encouraged a consensual relationship between the Habsburg court and domestic elites that positioned Hungary's political system between "western" European absolutism and the anarchical "royal republicanism" of Poland. The Habsburg claim to the entire kingdom helped sustain the vision of a united patrimony, ultimately realized following the triumph over the Ottomans and definitively confirmed in 1867. The combination of Hungary's borderline character and competing jurisdictions contributed to political instability during the $16^{\text {th }}$ and $17^{\text {th }}$ centuries. Only after the Habsburgs had pushed the Ottomans from the Hungarian plain, did the frontier begin a more conventional evolution. In a move that was a clear break with previous frontier arrangements, the Habsburgs and Ottomans clearly separated their territorial jurisdiction by drawing and demarcating the boundary that pacified the frontier regime more in keeping with general developments in Europe. Outer borders gradually assumed new functions. The permanent sanitary cordon that the Hasburgs established in 1728 along its entire length remained an unparalleled public health institution, effectively blocking the spread of plague from the Ottoman Balkans. In addition, it served as a migration control institution, signaling the ongoing transition to a modern international frontier, which would have been unimaginable without its mobility control function. This spacial transformation encouraged the kingdom's recovery and re-population, as well as its transition from a "borderland" into the "heart of Europe". The simultaneous colonization of Hungary from the west and southeast stimulated its economic and demographic recovery, while compounding its linguistic and ethnic diversity, particularly in border areas, thereby contributing to its dissolution in the age of nationalism.
\end{abstract}

Keywords: Hungary, early modern, transition, linear political borders, sanitary cordon, border

One of the staples of Habsburg history is the Czech historian František Palacky's exclamation that "If the Habsburg monarchy hadn't existed, it would have to be created." In fact, the monarchy was conceived in the late middle ages as a borderland and evolved into one of the continent's great powers by fulfilling that func- 
tion with Hungary serving as the leading edge of its expanding eastern frontier. By the middle of the $18^{\text {th }}$ century the dynasty's Austrian and Hungarian crown lands had transitioned from a "borderland" into the "heart of Europe" that now stretched to the Urals with two new players in its constellation of great powers. Over that time, the Habsburg Gesamtstaat transitioned not only in time but also institutionally between eastern and western Europe. My own scholarship has pointed to five principal attributes that defined Austrian exceptionalism, two of which are particularly germane to the subject of this volume and the conference from which it originated: the diplomacy of geopolitics and the reliance on consensus. ${ }^{1}$

First and foremost is the role that diplomacy played in a meteoric ascent that was deeply influenced by geopolitical calculus. Until the middle of the $18^{\text {th }}$ century the monarchy's central location was unique among the major continental powers. Both Spain stood at the end of the European peninsula while England readily evolved from hegemon to sole proprietor of the British Isles. France's essentially isthmian position greatly limited the number of potentially hostile neighbors. Like Spain and Britain, both Russia and the Ottoman empire benefited from privileged positions along the edges of the continent, along with massive stretches of uninhabited wasteland along their peripheries. If the Habsburg monarchy's central location exposed it to multiple threats, it also made it a valuable ally for other states against mutual adversaries. Indeed its greatest virtue rested in being sufficiently strong to serve as an effective counterpoise without being so powerful as to threaten the long-term security of its putative allies. Over the centuries, Machiavelli's dictum that neutral powers side with the weaker of any two belligerent powers was a prescription for allying with the House of Habsburg.

Admittedly, the monarchy's exposed central location brought with it the heavy burden of defending multiple frontiers, sometimes simultaneously. While their Ottoman adversary could typically pick and choose its preferred theater of operations and then act unilaterally, the monarchy was compelled to react to threats from multiple points of the compass, practicing a strategic triage designed to parry the blows of its enemies, rather than vanquish and occupy them. Historians have long appreciated the East-West dilemma that successive emperors confronted in the $16^{\text {th }}$ and $17^{\text {th }}$ centuries when choosing whether to repel threats in and around Germany or in the Balkans. Less obvious were incipient threats that emerged in the $18^{\text {th }}$ century in Italy and Poland. A more comprehensive understanding of Habsburg statecraft visualizes all four areas as vital buffers that had to be vigilantly protected from salient military threats. Whenever any one of these four glaces was breached, the Habsburgs worked to restore it by all available means. ${ }^{2}$ The first test came in Germany with the Reformation and in the Balkans following the Ottoman conquest of most of Hungary; hence the ensuing succession of Austro-Turkish wars that ended with the reconquest of the Hungarian plain. Just as this task was being completed, the extinction of the Spanish Habsburgs obliged 
Emperors Leopold I (1657-1705), Joseph I (1705-11) and Charles VI (1711-40) to wrest control of Italy from the Bourbons, a struggle that began with the War of Spanish Succession (1701-14) and continued through 1748. By then, Frederick II's infamous rape of Silesia inspired Empress Maria Theresa (1740-80) to devote her entire reign and four "Silesian wars" to restoring the dynasty's previously hegemonic position in Germany. By then, Maria Theresa had resolved the Polish security crisis that had begun with the Great Déluge (1655-60), continued through the diplomacy during the Great Northern War (1700-21) and ended with the creation the monarchy's Galician glacis during the First Partition of the royal republic (1772).

If each Habsburg monarch employed different approaches in meeting these and other security crises, their exposed position necessitated that they strive for consensus in recruiting the largely voluntary support of the monarchy's foreign allies and domestic elites. This required remaining true to dynastically legitimate goals that invariably respected the territorial integrity of weak neighbors in all four regions. For good measure, successive emperors refrained from acting unilaterally prior to Emperor Francis Joseph's preemptive actions in Italy (1859), Bosnia (1878) and Serbia (1914). It also constrained the emperor to respect the privileges and other interests of domestic stakeholders, both to ensure their support and to dissuade them from fomenting rebellion - perhaps in conjunction with hostile foreign powers.

The necessity to compromise and forge consensus with them created a "transitional" state and society with institutions and values that represented an amalgam of East and West. Although successive emperors subscribed to the mantra of "one king, one law, one god" that inspired their Spanish cousins, the French and Spanish Bourbons, and the British Stuarts, they reluctantly forewent the option of progressive governmental centralization that ultimately created culturally and linguistically homogenous polities across Europe's western face. Even after Ferdinand II imposed the Verneuerte Landesordnung on the vanquished Bohemian lands in 1627, their estates continued to negotiate and collect tax levies until the middle of the $18^{\text {th }}$ century - just as did their Austrian and Hungarian counterparts. ${ }^{3}$ Thus, the monarchy's estates reflected a constitutional middle ground between the "western" European absolutism of Portugal, Spain and France and "eastern" European models that ranged from the "Asiatic despotism" of tsars and sultans to the anarchical "royal republicanism" of Poland which retained elective kingship long after the institution had been discontinued in Bohemia (1627) and Hungary (1687). Which is not to fault either the Habsburgs for their timidity or the estates for their feudal obstinacy. As Fareed Zakaria has pointed out, the monarchy's mix of feudal absolutism and constitutionalism represented a form of "liberal authoritarianism" that protected human and civil rights better than most of the newly forged democracies of post-Communist Europe. ${ }^{4}$ 
Similarly, the Habsburgs were no more accepting of religious dissenters than their counterparts in the West but were nonetheless obliged to tolerate both Protestant and Orthodox Christians throughout most of their extensive Hungarian lands, much as the Ottomans favored them over Catholics in their own Hungarian lands. Certainly the survival of religious sects like Bohemia's Utraquists and Hungarian Unitarians were as much unlike western Europe as the large percentage of Jews in both kingdoms. Moreover, at a time when western Europeans were gradually adopting a single received language, all three of the monarchy's core lands remained as linguistically diverse as the Ottoman Balkans, Polish Confederation and Russian empire - and becoming more so with the persistent immigration of Orthodox Serbs and Romanians to Hungary. The monarchy's confessional and linguistic diversity was famously evident along the $1,900 \mathrm{~km}$. long Military Border, where Serbs, Croats, Romanians, Szeklers, Vlachs and Germans shielded the monarchy from Ottoman incursions. Indeed, the Habsburg military establishment constituted another example of its transitional position within the European state system. The regular army could hold its own in conventional operations against France, Sweden and, eventually, Prussia in the West, but also featured the irregular formations and tactics of the celebrated Grenzer, Uzkok privateers, freelancing heyducks, and paramilitaries raised by Hungarian estate owners that paralleled Russian Cossacks and Turkish bashi-bazooks in the East. The same contrast obtained between the monarchy's stable western frontier and the erratic tempo and tactics along a Military Border that acted more like a line of scrimmage with "peacetime" raids bent on looting and kidnapping civilians for ransom; of course, these hazards were also common to those living along the Ottomans' Black Sea littoral or opposite the shores of Africa's Barbary Coast.

The monarchy's economy was no less transitional. Its Austrian and Bohemian lands sported significant industrial and commercial infrastructure and output to go with a self-sustaining agricultural base; the subsequent acquisition of the Spanish Netherlands and Lombardy added substantially to this bounty. Meanwhile, the Ottoman invasions devastated the commercial economy of Hungary's royal towns and forced much of the peasantry to forsake agriculture for livestock raising. ${ }^{5}$ Those of Hungary's peasants who continued to till the soil generally paid for the privilege and protection of Hungary's magnates by being reinserfed. Once again, the "second serfdom" was a phenomenon that prevailed throughout the East - including Bohemia and Germany's East Elbian landscape - but was unknown in the monarchy's discontiguous western dominions or in the Austrian lands, although the prevalence of compulsory labor service in the archduchies and Inner Austria represented a middle ground between Europe's free Western and enserfed Eastern peasantry. If there was an exception to the East-West axis that defined the monarchy's structural orientation, it was in the world of culture. By the late $16^{\text {th }}$ century, the dynasty had wholeheartedly embraced a Counter-Refor- 
mation mentalité and representative Baroque forms that were more southern European; aside from southern Germany this, too, distinguished the entire monarchy not only from the Orthodox and Muslim East, but from Protestant northern Europe and even from the Baroque forms adopted in Catholic France. If we are to believe R.J.W. Evans, the mindset of the Habsburg Baroque was inherently irrational to the point of accepting the traditional forms in defiance of philosophical trends that were just beginning to seize the imagination of French, British and Protestant German high culture. ${ }^{6}$

o what extent did the Ottoman presence on its southern frontier affect this Transitional Empire? Certainly, it had a major impact, although its duration was finite both in time and consequences. The Ottoman-Habsburg relationship can be divided into three periods: (1) a confrontational phase (1526-1699) when the two were committed enemies, with neither side willing to recognize the other's legitimacy, (2) a transitional period (1700-68) when the Ottomans feared, respected and recognized the emperor who, in turn, no longer deemed the Ottomans a threat to the monarchy's security and accepted them as a tolerable presence along the borders of his empire at a time when Prussia and Russia had emerged as much more formidable neighbors, ${ }^{7}$ and (3) a standing policy of preserving the Ottoman empire (1769-1918) that began with its crushing defeats in the Russo-Turkish War of 1768-74. Much of our focus here will be on the first period, during which the Ottoman impact on the monarchy - and on Hungary in particular - has been judged quite negative. Certainly this was the view of the emperors' contemporaries and subjects, many of whom lived in fear of Turkish raids and invasions, against which all of the core lands bore the burdens of taxation and military service.

Otherwise it is unclear how negatively Turkish threat impacted the monarchy as a whole. Certainly the dynasty and monarchy itself drew strength throughout its history from the succession of crises that built consensus, prompting badly needed internal reform and eliciting sometimes massive assistance from neighboring countries. After all, the Turks' first appearance on the Hungarian plain provided the most convincing raison d'être for the monarchy's existence that led to prodigious growth through the acquisition of Bohemia and Hungary. It also buttressed its successful pretensions to leadership of the often fractious German nation. Perhaps most important of all, the Turkish challenge greatly enhanced the unity of the core lands, with Hungary relying heavily on Austrian and, especially, Bohemian financial and human resources, while the German Erblande greatly appreciated Hungary's survival and continued role as a buffer between them and the dreaded Turks. But there were limits to the bounty of the Türkengefahr. Whereas the great- 
est benefits invariably accrued from existential crises that threatened the monarchy's very existence, the Habsburgs themselves never viewed the Ottoman menace as a death threat. Admittedly the Turks themselves bore some responsibility for this. With the minor exception of Sultan Suleiman's Hungarian campaigns of 1554-56, they never attacked the monarchy when it was fully engaged elsewhere. Even if such a Dolchstoss fell short of a fatal blow, it would have at least forced the emperor to conclude an unfavorable peace with his Christian adversaries. Yet, the sultan remained steadfastly neutral throughout the Thirty Years' War, during the four wars of succession that consumed the monarchy's attention for much of the $18^{\text {th }}$ century, and in its subsequent struggle with revolutionary France. On two occasions during the Thirty Years' War and the Great Déluge he even frustrated Swedish operations against the monarchy's forces by recalling its Transylvanian surrogates from Hungary. ${ }^{8}$

Remarkably enough, the Habsburg-Ottoman wars did not by themselves significantly change either empire's overall political, economic, or cultural structure for the simple reason that the monarchy never felt sufficiently threatened. Although the Ottomans twice besieged Vienna, they never shook the confidence of the policy makers in Vienna, who felt that any losses would be but temporary, both because of their access to support from allies and because of the logistical problems that constrained the sultan's forces. If anything, the Turkish threat obliged successive emperors to retain the existing governmental and socio-economic system, albeit one that evolved within the cultural framework of Counter-Reformation. Right up until 1683, they gave precedence to meeting threats in the West, both because land there was seen as more valuable while territory lost in the East could be more easily recovered. The triumphant Holy League (1684-99) vindicated this calculus, further entrenching the monarchy's triarchical power structure, which celebrated its apotheosis with the self-congratulatory flourishes of the High Baroque right up until $1740 .{ }^{9}$ Rather, systemic change came only with the sudden loss of Silesia and the realization that the Prussian threat was truly existential.

Which is not to say that the Ottoman challenge did not elicit some additional benefits. Among the best-known was the Military Border which facilitated the restoration of agriculture, programmatic resettlement, and a general state of normalcy to the rest of the Hungarian plain, Transylvania and Croatia. ${ }^{10}$ Meanwhile, its Grenzer formations eventually grew to roughly a quarter of the Habsburg military and were eventually employed elsewhere in Europe at a fraction of the cost of regular army units. ${ }^{11}$ The Habsburg-Ottoman frontier itself also contributed to the evolution of modern international borders. 


\section{Linear Boundaries}

Sixteenth- and $17^{\text {th }}$-century Hungary was, in fact, a giant Habsburg-Ottoman borderland. The frontier was heavily militarized, dotted with fortresses and smaller fortifications. On the Habsburg side, border areas were organized into the Military Border, stretching from Adriatic Sea to the Carpathian mountains in what is today Slovakia. A similar organization existed in Ottoman frontier provinces. The provinces deeper inside both empires participated as well, sending soldiers and subsidies to the frontier. Even in official peacetime, there persisted a low intensity Kleinkrieg that featured intermittent raids, robberies, and kidnappings for ransom. Moreover, jurisdictions overlapped, with Hungarian nobles claiming feudal rights over certain communities on the Ottoman side of the border. The peasants in areas where jurisdictions overlapped were taxed twice. ${ }^{12}$ Intermittent peacetime violence, insecurity, and competing jurisdictions were unusual in other parts of Europe. However, in many other aspects, the Habsburg-Ottoman border was not atypical during this period. For example, France's border with the Spanish Netherlands was also heavily fortified. ${ }^{13}$ Central governments across the continent were organizing frontiers as defensive zones and had little interest in precisely defining their boundaries. Instead, the concept of sovereignty was based on the personal patrimonial bond between the ruler and his subjects. All rights and jurisdictions, such as the rulers' responsibility to defend their subjects, derived from this relationship. In this arrangement, precise territorial limits were not important and were considered a matter of purely local significance. ${ }^{14}$

That changed at the end of the $17^{\text {th }}$ century, when the Habsburg-Ottoman frontier was profoundly transformed by the peace congress of Carlowitz (1698-99). During the negotiations the Ottoman representatives proposed to organize the new border as a demarcated linear boundary. They were not unfamiliar with such a solution, having previously regulated their boundaries with Venice, Poland-Lithuania and other neighboring countries. ${ }^{15}$ The Carlowitz settlement introduced other changes, including the border's total pacification from the moment that peace was concluded. Not only were robberies, abductions, and attacks of any sort strictly forbidden, but perpetrators were to be severely punished. A joint border commission traveled the course of the new frontier 1699-1701 determining the precise borderline by placing markers, such as piles of earth and wooden poles, then carefully describing them in delimitation protocols. The Habsburg side also created a series of maps representing the new border. ${ }^{16}$ Both parties recognized each other's territorial sovereignty by clearly separating their jurisdictions over space and subjects. They even reduced the number of the existing border fortifications and prohibited the construction of new ones. Henceforth, their subjects were to be allowed to live in peace and security, despite their proximity to the border. 
With the peace of Carlowitz, central governments assumed greater responsibility for their international borders. Rather than employing the traditional inventories of jurisdictions and rights that were standard in other parts of Europe, they introduced technical and abstract knowledge in the form of maps and demarcation protocols. With the information collected, the Habsburg central government could ideally redraw the borderline without local help and experience. In many cases, the central government actually disregarded or ignored local interests. In 1703, the Habsburg military expelled its subjects from their homes near the Bosnian town Novi, resolving the last territorial dispute with the Ottomans. At the later treaty of Sistova (1791) the Ottomans ceded a narrow strip of land in western Bosnia to the Habsburgs without consulting the locals, who were then instructed to sell their property on the "wrong" side of the new border. ${ }^{17}$ The new role of central authorities marks a gradual transition from personal patrimonial to a visually defined territorial concept of jurisdiction. ${ }^{18}$ It is visible in changing attitudes toward cross-border mobility. The Carlowitz Peace Treaty of 1699 allowed the joint use of the Maros (Mureş), Tisza and Sava Rivers, including the islands along them, with local residents freely crossing the line. During the Rákóczi Rebellion (1703-11), the Habsburg commanders carried correspondence through the Ottoman territory. The Ottoman governors complained only when armed Habsburg militiamen fleeing Hungarian rebels entered the Ottoman Banat without first seeking permission. In 1739, a stricter concept of territorial sovereignty was introduced. Physical space and the borderline in particular became an important part of state's identity. The smallest border infringements were therefore viewed not as local incidents, but as challenges to state sovereignty. From that moment on, not even fishermen were allowed to cross the line, which divided the river frontiers in two. The Habsburg court complained when local Ottoman subjects did not adhere to this provision. ${ }^{19}$ Similar processes in southern, western and central Europe began several decades later. ${ }^{20}$ Yet by then the Habsburg border with the Ottomans had gone one step further with the introduction of a permanent mobility control regime in the form of sanitary cordon.

\section{Sanitary Cordon}

The most fearsome epidemic of that time, the plague, was endemic in many parts of the Ottoman Empire. By the $14^{\text {th }}$ century, Europeans had begun to realize that the only effective measure was the isolation of infected areas and of people coming from there. If a sequestered individual did not show signs of disease for a certain period of time (typically 40 days), s/he was considered healthy and allowed to continue traveling. From the $15^{\text {th }}$ century onwards, most European ports established quarantine facilities and began sequestering all ships coming from the East- 
ern Mediterranean. Epidemics spreading by land were harder to contain. Whole provinces had to be isolated by a protective cordon, across which all communication was strictly supervised, usually by the military, allowing only persons who underwent quarantine to pass. Such measures were introduced during the last epidemic of plague in western Europe, when France and neighboring countries successfully contained the epidemics that broke out in Marseille in 1720-22 within the county of Provence..$^{21}$ Yet such protective cordons were temporary and were disbanded as soon as the danger passed.

When a plague epidemic swept through Hungary in the final phase of the Rákóczi Rebellion (1703-11), Emperor Joseph I ordered the formation of the temporary land sanitary cordon (Pestfront, Kordon) between Hungary and Inner Austria (1710). All travel and trade was redirected through heavily guarded quarantine stations that effectively prevented unauthorized contact. ${ }^{22}$ Once the danger had passed the central government abolished the cordon much as other European states had. Yet the monarchy's long and relatively porous land border with the Ottoman Empire placed it in a far more exposed position that demanded more than temporary measures. After all, plague epidemics regularly infested the Ottoman frontier provinces, placing Habsburg Hungary and, ultimately, the Erblande in permanent danger. In 1728, Emperor Charles VI established a permanent sanitary cordon along the entire Ottoman frontier. ${ }^{23}$ Although this first effort collapsed during the Habsburg-Ottoman war of 1737-39, a second, more definitive Pestfront was erected following the Peace of Belgrade (1739) that lasted until $1857 .{ }^{24}$

The sanitary cordon was a formidable institution, stretching roughly $1,900 \mathrm{~km}$ from the Adriatic Sea to Poland. For the most part, it followed natural lines and barriers such as the Una, Sava, and Danube Rivers and the Carpathian Mountains. It was closely monitored from watchtowers and through regular patrols to prevent unauthorized crossings. Illegal immigrants and their accomplices were tried before criminal or martial courts without the right of appeal and subject to severe punishment. ${ }^{25}$ By the 1760 s, when the Military Border expanded eastward into the Banat of Temesvár and Transylvania, replacing less effective service by local peasants, the entire sanitary cordon was congruent with outer boundaries of the Military Border. By 1776, the military administration had proven so effective that the sanitary personnel were placed under the direct authority of the War Council. ${ }^{26}$ In 1770 , the border could be crossed through nineteen quarantine stations, approximately one every $100 \mathrm{~km}$. Here, the incoming travelers were identified, registered both locally and in the central records in Vienna, and provided with personal identification documents, passports and sanitary certificates (SanitätsFoede). The quarantine time usually ranged from 21 to 42 days. ${ }^{27}$ Initially border control and supervision had two official purposes: protecting public health while preserving uninterrupted trade with the Ottoman Empire. By 1752, however, the central government officially acknowledged other functions, such as the preven- 
tion of banditry, espionage, contraband, desertion, and unwanted peasant emigration, as well as the safe bilateral use of border resources that included pulling barges upstream on whichever side of the river was more convenient. ${ }^{28}$ Meanwhile, the cordon consistently vindicated its initial raison d'être by blocking the spread of several outbreaks of plague. ${ }^{29}$

In addition to being one of few linear boundaries in Europe, the Habsburg-Ottoman border was very advanced as a migration control institution for its time. It is difficult to find comparable systematic and comprehensive countrywide mobility control regimes in other parts of Europe. Similar regimes were eventually introduced in most European states after the French Revolution and especially after 1918. ${ }^{30}$ In this respect, the Habsburg-Ottoman frontier signaled the evolution of the modern international frontier, which would be unimaginable today without its mobility control function. Specific needs and circumstances gradually produced quite a novel arrangement in the southern areas of Hungary, an important contribution to the development of the state and governance in modern times.

Whereas Hungary shared in the benefits of the Grenzer formations and sanitary cordon that protected it as well as the rest of the monarchy, the Ottoman impact on the kingdom was nothing short of catastrophic. The Malthusian demographic consequences have attracted scholarly research for generations. The initial Ottoman marches up the Danube valley in 1529 and 1541 reduced the levels of habitation by $70-90 \%$ through mass flight to Upper Hungary. As a result of this shift, population densities in the Hungarian plain fell to roughly half of the northern and western counties that formed the rump of Habsburg Royal Hungary. Thereafter, campaigning armies of both sides grievously afflicted the civilian populations across the kingdom, particularly during Long War (1591-1606). Although the latest data records marginal increases in population under Turkish rule, this was likely due to steady immigration of Serbs, Romanians and others who were drawn from the Ottoman Balkans with incentives from Hungarian estate holders who were eager to repopulate their depleted estates. ${ }^{31}$ The Habsburg reconquest was attended by the forced emigration of Turkish and other Muslim settlers, including 100,000 from the Banat at the end of the Austro-Turkish War of 1716-18. Two decades later, most of the colonists who had settled there were wiped out by wartime flight and disease. A sustained colonization program under Maria Theresa and Joseph II successfully repopulated the Hungarian plain and Transylvania well beyond pre-Ottoman levels. Nonetheless, the massive influx of Reich Germans and Habsburg subjects from the north and west, together with the concurrent immigration of Ottoman Serbs and Romanians from the south greatly reduced the Magyars themselves to a minority in their own country. The resulting linguistic 
and confessional diversity of greater Hungary presaged the $19^{\text {th }}$-century nationalities conflicts and the kingdom's partition at Trianon [Treaty of Trianon, 1920].

Ottoman Hungary's demographic upheaval was attended by unfortunate socio-economic developments. The aforementioned commercial losses sustained by the royal towns reduced the size and strength of the bourgeoisie, even as the ranks of the nobility swelled through the ennoblement of fighters against the Turks and the wealth of reconverted Catholic magnates appreciated with royal patronage and the wholesale adoption of estate capitalism. ${ }^{32}$ Nor was the subsequent reconquest an unmitigated blessing. At no point during the Ottoman occupation had the government in Vienna psychologically accepted Royal Hungary as an equal constituent in the Habsburg Gesamtstaat. At a time when the Bohemia was earning equal billing with the Austrian crown lands as conjoint parts of the German "hereditary lands" or Erblande, Hungary never earned this appellation even after the Sopron Diet (1687) had adopted the Habsburg male line's right to hereditary succession. Hungarians were almost never admitted to the emperor's most powerful decision-making councils, which remained the exclusive domain of Austrian and German-speaking Bohemian nobles, plus a smattering of Italians and Reich Germans. As late as 1740 the kingdom existed as a discrete territorial appendage to be taxed, colonized and employed as a glacis against Ottoman empire.

Although the policy of extralegal taxation ended with Leopold I, his successors circumscribed the Hungarian and Croatian diets' jurisdiction over the Military Border, Banat, and Transylvania by entrusting their administration - including colonization efforts - to the Hofkriegsrat and Hofkammer. Nobody could have anticipated the role that the Habsburg kings' "southern strategy" would have in abetting the autonomist pretensions of the kingdom's non-Magyar populations. Nonetheless, the resettlement and administrative restructuring of the kingdom's neo acquistica conceived and incubated a diversity that would contribute to the kingdom's dissolution in 1918.

Much as the Ottoman invasion doomed Hungary to two centuries of political, demographic, and economic decline, it was the Prussian descent on Silesia in 1740 that shocked Vienna into adopting dramatic structural changes that greatly benefited the monarchy - including Hungary. This is not the place to recount the recovery that began under Maria Theresa. But it is appropriate to identify the admittedly few advantages that the kingdom derived from its difficult two-century-long division as a Habsburg-Ottoman borderland. If nothing else, the enduring Habsburg claim to the entire kingdom helped sustain the vision of a united patrimony that would not have been a priority for other invaders who would have readily dismembered it. The separately administered entities were themselves restored incrementally by Maria Theresa (Banat), Joseph II (Transylvania), and Francis Joseph (Vojvodina, Military Border). Although the kingdom's constitu- 
tion was ignored or abrogated altogether on several occasions, it was periodically reaffirmed, most notably at Sopron (1687), Szatmár (1711) and definitively by the Dual Compromise of 1867, while the Austrian and Bohemian lands remained submerged in the conglomerate of crown lands collectively known as Cisleithania. Indeed, unlike all of the other Habsburg dominions - Austria and Bohemia, as well as the Austrian Netherlands, Lombardy, Galicia and Bosnia - Hungary is the only component of its patrimony that has continuously maintained the status of an independent state, albeit in the truncated form rendered at Trianon.

\section{References}

1 Ingrao, Charles, 2000. The Habsburg Monarchy, 1618-1815. Cambridge: Cambridge University Press, $2^{\text {nd }}$ ed., 2-22.

2 Ingrao, Charles, 1982. Habsburg Strategy and Geopolitics in the Eighteenth Century. In Béla Király, Gunther E. Rothenberg, and Peter Sugar, eds., War and Society in East Central Europe, II [Brooklyn College Studies, XI], 49-66.

3 Hassenpflug-Elzholz, Eila, 1982. Böhmen und die böhmischen Stände in der Zeit des beginnenden Zentralismus: Eine Strukturanalyse der böhmischen Adelsnation um die Mitte des 18. Jahrhunderts. Munich: Oldenbourg.

4 Zakaria, Fareed, 1997. The Rise of Illiberal Democracy. Foreign Affairs 76, 22-43.

5 Barta, János, 2001. Habsburg Rule in Hungary in the Eighteenth Century. Hungarian Studies Review, XXVIII, 137.

6 Evans, R.J.W. 1979. The Making of the Habsburg Monarchy, 1500-1750: An Interpretation. Oxford: Clarendon Press.

7 Grothaus, Maximilian, 1983. Zum Türkenbild in der Kultur der Habsburgermonarchie zwischen dem 16. und 18. Jahrhundert. CIEPO Colloque; Sutter Fichtner, Paula, 2008. Terror and Toleration: The Habsburg Empire Confronts Islam, 1526-1850. London: Reaktion, 96.

8 Höbelt, Lothar, 2008. Ferdinand III: Friedenskaiser Wider Willen. Graz: Ares, 46, 236-37; Hengerer, Mark, 2012. Kaiser Ferdinand III. (1608-1657): eine Biographie. Vienna: Böhlau, 233.

9 Ingrao, Charles 2001. Die Transformation der österreichischen Barockmonarchie von ihrer Schaffung bis zum Zusammenbruch. In: Peter Burgard, ed., Barock: Neue Sichtweisen einer Epoche. Vienna: Böhlau, 85-100.

10 As William McNeill (1964) noted, it was the return from itinerancy dependent on animal husbandry to established settlements engaged in agriculture that effectively closed Hungary's frontier society by the mid- $18^{\text {th }}$ century (Europe's Steppe Frontier 1500-1800. Chicago: University of Chicago).

11 Dickson, P.G.M. 1987. Finance and Government under Maria Theresia, 1740-1780. Oxford: Clarendon Press, II: Finance and Credit, 354.

12 Ágoston, Gábor, 2003. A Flexible Empire: Authority and its Limits on the Ottoman Frontiers. International Journal of Turkish Studies, 9 (1-2), 15-32, here 24.

13 Nordman, Daniel, 1998. Frontières de France: de l'espace au territoire : XVIe-XIXe siècle. Paris: Gallimard, 233, 235, 250-51.

14 Febvre, Lucien, 1962. Frontière: le mot et la notion; Frontière: limites et divisions territoriales de la France en 1789. In: Lucien Febvre, 1962. Pour une Histoire à part entière, Paris: S.E.V.P.E.N., 18-19; Sahlins, Peter, 1989. Boundaries. The Making of France and Spain in 
the Pyrenees. Berkeley: University of California Press, 78; Nordman, 1998. Frontières de France, 128-29.

15 Abou-El-Haj, Rifa'at A., 1967. Ottoman Diplomacy at Karlowitz. Journal of the American Oriental Society, 87 (4), 503-5; Pedani, Maria Pia, 2002. Dalla frontiera al confine. Venice: Herder; Kolodziejczyk, Dariusz, 2000. Ottoman Polish Diplomatic Relations $\left(15^{\text {th }}-18^{\text {th }}\right.$ Century): An Annotated Edition of 'Ahdnames and Other Documents. Leiden: Brill, 137, 152-3, 157-8; Kołodziejczyk, Dariusz, 2012. Between Universalistic Claims and Reality: Ottoman Frontiers in the Early Modern Period. In: Christine Woodhead, ed. The Ottoman World. Abingdon, UK: Routledge, 205-19, here 207-12.

16 The Carlowitz Peace Treaty, January $26^{\text {th }}$, 1699, articles 2-9, 18, http://www.ieg-mainz.de/ likecms $/$ likecms.php? site $=$ site. $h$ tm \&dir $=\&$ nav $=233 \&$ siteid $=133 \&$ treaty $=428 \&$ lastsiteid $=7$ $7 \&$ searchquery $=\% 26$ is_fts $\% 3 \mathrm{D} 1 \% 26$ filter_select $\% 3 \mathrm{D} \% 26$ filter_wt $\% 3 \mathrm{D} \% 26$ filter_id $\% 3 \mathrm{D}$ $\% 26$ filter_1\%3D\%26filter_p $\% 3 \mathrm{D} \% 26$ searchlang\%3Dde\%26searchstring\%3DKarlowitz\% 26date\%3D\%26year_from\%3D\%26year_till\%3D\%26location\%3D (Accessed February $\left.26^{\text {th }}, 2013\right)$.

The Ottoman delimitation protocol between Bosnia and the Habsburg Monarchy is published in: Kovačević, Ešref, 1970-71. Hududnama Bosanskog vilajeta prema Austriji posle Karlovačkog mira. Kritičko izdanje teksta. Prilozi za orijentalnu filologiju, 20-21, 365-436. The Habsburg maps of delimitations: Mappa geographico Limitanea in qua Imperiorum Caesarei et Ottomannici Confinia in almae pacis Carlovitzensis congressu decreta et duobus utrius que imperi Commissaris instituta solennie expeditione, [c. 1700], Österreichisches Staatsarchiv, Vienna, Kriegsarchiv (hereafter OeStA/KA), KS, b IX c 634 (album).

17 Gavrilović, Slavko, 1994. Srbi u Hrvatskoj od Bečkog rata do rata 1716-18. In Istorija srpskog naroda. Belgrade: SKZ, vol. 4, no. 1: 65, 68; The Treaty of Sistova, August $4^{\text {th }}, 1791$, Article 8, OeStA/Haus- Hof- und Staatsarchiv (Hereafter OeStA/HHStA), StAbt Türkei III 7. It is not clear to which private property this article refers. At least in theory arable land was the property of the Ottoman sultan and his subjects could only own their houses and gardens. The reality was obviously different at the end of the $18^{\text {th }}$ century.

18 For more on this subject, see Sahlins, Boundaries.

19 The Carlowitz Peace Treaty, articles 2 and 5; Globitz to the War Council, Szeged, July $9^{\text {th }}$, 1709, OeStA/HHStA StAbt Türkei I 178; The translation of the firman to the Firari Mustafa Pasha, the governor of Belgrade, November 1755, OeStA/HHStA StAbt Türkei III 4.

20 See footnote 13

21 Panzac, Daniel, 1999. Politique sanitaire et fixation des frontières: l'exemple Ottoman (XVIIIe-XIXe siècles). Turcica, 31, 91-2; Sahlins, Boundaries, 75-7.

22 Pest Ordnung, October $14^{\text {th }}, 1710$, OeStA/ Finanz- und Hofkammerarchiv (hereafter FHKA) SUS Patente 43.15; Ingrao, Charles W., 1979. In Quest and Crisis: Emperor Joseph I and the Habsburg Monarchy. West Lafayette, IN: Purdue University Press, 216.

23 Patent from October $22^{\text {th }}, 1728$, Lesky, Erna, 1957. Die österreichische Pestfront and der k. k. Militärgrenze. Saeculum, 8, 84.

24 The sanitary cordon ceased to exist effectively in 1857. It continued to exist on paper until the 1870 s, when it was formally abolished together with the Military Border. Rothenberg, Gunther E., 1973. The Austrian Sanitary Cordon and the control of Bubonic Plague: 1710-1871. Journal of the History of Medicine and Allied Sciences, 28 (1), 21-3.

25 Festsetzung der Todesstrafe..., Vienna, January $16^{\text {th }}, 1740$, OeStA/FHKA SUS Patente 74.2; Erneuerung der Kontumaz-Ordnung, August $25^{\text {th }}, 1766$, OeStA/FHKA SUS Patente 159.31. The usual sentence was several years of hard labor (Schanzarbeit). The death penalty seems to have been carried out only in exceptional cases.

26 Lesky, Die österreichische Pestfront, 84-90, 92. 
27 Generalsanitätsnormativum, January $2^{\text {nd, }} 1770$, Sammlung aller $k$. $k$. Verordnungen und Gesetze vom Jahre 1740. bis 1780 ..., 8 vols., Vienna: Johann Georg Mößle, 1786, vol. 6 (1770-1773), no. 1152. In the 1760 s, the quarantine could last up to 84 days. In 1785 , the quarantine duration significantly decreased, with no quarantine when there was no plague in the Balkans. Some examples of local quarantine records: [Weekly] Contumaz- Tabella, November $9-16^{\text {th }}, 1742$, Zemun (Semlin), November $16^{\text {th }}, 1742$, OeStA/KA ZSt MilKom Sanitätshofkommission Akten 1, 1742-November-3.

28 Maria Theresa to the Banat Provincial Administraton, Vienna, March $27^{\text {th }}, 1761$, OeStA/KA ZSt MilKom Sanitätshofkommission Akten 1, 1761-Martius-5; Anmerkungen über von H. Dr. Grosse... eingeschickten Vorschlag, Vienna, 1752, OeStA/KA ZSt MilKom Sanitätshofkommission Akten 1, 1755-8; Bartenstein to Maria Theresa, Vienna, September $14^{\text {th }}, 1762$, OeStA/KA ZSt MilKom Sanitätshofkommission Akten 1, 1762-September-13.

29 Such as the plague in Srem (Syrmia) at the end of the $18^{\text {th }}$ century. Schraud, Franz, 1802. Geschichte der Pest in Syrmien in den Jahren 1795 und 1796. 2 vols., Pest: Mathias Trattner.

30 Burger, Hannelore, 2000. Passwesen und Staatsbürgerschaft. In: Waltraud Heindl and Edith Sauer, ed. Grenze und Staat. Paßwesen: Staatsbürgerschaft. Heimatrecht und Fremdengesetzgebung in der österreichischen Monarchie 1750-1867. Vienna: Böhlau, 1-172; Geselle, Andrea, 2001. Domenica Saba Takes to the Road: Origins and Development of a Modern Passport System in Lombardo-Veneto; Lucassen, Leo, 2001. A Many-Headed Monster': The Evolution of the Passport System in the Netherlands and Germany in the Long Nineteenth Century; Torpey, John, 2001. The Great War and the Birth of the Modern Passport System. In: Jane Caplan and John Torpey, ed. Documenting Individual Identity: The Development of State Practices in the Modern World. Princeton: Princeton University Press, 199-217; 235-55; 256-70.

31 Barta, János, Habsburg Rule in Hungary, 136-38, and Pálffy, Géza, 2001. The Impact of Ottoman Rule on Hungary. Hungarian Studies Review, XXVIII, 116-18, 121-3.

32 Pálffy, Géza, 2010. Povijest Maðarske: Ugarska na granici dvaju imperija (1526-1711) [The History of Hungary: Hungary on the Border of Two Empires]. Zagreb: Meridijani, 199-201. 